\title{
The Economic Structure and Employment Opportunities (Cases in Bengkulu, Indonesia)
}

\author{
Imron Rosyadi and Cicih Ratnasih
}

\section{ABSTRACT}

\begin{abstract}
This study examines the effect of changes in the economic structure on employment opportunities in Bengkulu Province and determines the necessary economic policies. Besides, this study also aims to measure and compare all economic sectors and the total sector productivity of each sector. The method used is explanatory research. The subjects in this study were Bengkulu Province. The data used in the measurement of research variables are secondary in time in data series from 1983-2017. It is for 34 years. The required data is from the Central Bureau of Statistics (CBS) Bengkulu Province. Hypothesis testing was analyzed using Multiple Linear Regression Analysis. The result showed that changes in the economic structure had a simultaneous effect on job opportunities. The agriculture sector's contribution is positively more influence, the electricity and drinking water sector, the transportation and communication sector, the trade and hotel sector, and the services sector. Changes in Economic Structure have a simultaneous effect on job opportunities. Partially, job opportunities are more positively influenced by the contribution of the agricultural sector (X1), buildings (X4), electricity and drinking water (X5), transportation and communication (X6), trade and hotels (X7), financial and rental sector variables. Rent (X8) and services (X9). The increased contribution from these sectors can increase job opportunities to be higher. In this model, the magnitude of the effect simultaneously is $\mathrm{R2}=66.1 \%$. The remaining $33.9 \%$ can explain by other factors not examined, such as education, health, environmental, and performance factors.
\end{abstract}

Keywords: Direct Productivity Activity, Economic structure, Employment opportunities, Multiple Linear Regression, sectoral employment.

\author{
Submitted : August 27, 2021 \\ Published : September 27, 2021 \\ ISSN: $2507-1076$ \\ DOI: $10.24018 /$ ejbmr.2021.6.5.1074 \\ Imron Rosyadi \\ Universitas Ratu Samban, Indonesia. \\ (e-mail: ratusambanuniversitas@ gmail.com) \\ Cicih Ratnasih* \\ Universitas Borobudur, Indonesia. \\ (e-mail: cicih_ratnasih@borobudur.ac.id)
}

*Corresponding Author

\section{INTRODUCTION}

The number of workers absorbed in various economic sectors in Bengkulu Province in 2017 totaled 725,968 people. During 1998-2017, the labour condition in Bengkulu Province tended to increase from the previous of 622,512 people in 1998. In the economic structure, the Bengkulu Province workforce is still dominated by contributions from the agricultural sector: trade, hotel and restaurant, and services. The agricultural sector still dominates other sectors with an average contribution of $68.42 \%$. Followed by the trade, hotel, and restaurant sector at $11.87 \%$; and the services sector at $10.70 \%$. The manufacturing sector has a contribution to labour absorption, which is relatively similar to that of the construction sector and the transportation and communications sector. The contributions of the three sectors were $2.44 \%, 2.60 \%$, and $2.64 \%$, respectively. This value is still below the agricultural sector's contribution: trade, hotel and restaurant, and services. Reviewing its development from year to year, each sector's relative contribution to labour absorption has not changed significantly. Based on labour productivity, the financial, leasing, and corporate services sector was the highest productivity sector than other sectors with average productivity of 17,235 . It follows the mining sector $(5,465)$, the transportation and communication sector $(4,774)$, and the electricity, gas, and clean water sector $(2,993)$.

The explanation is interesting to examine which sectors develop to stimulate job opportunity growth in Bengkulu Province. The problems that have not been resolved by the local government are as follows: Not able to properly manage existing natural potential resources. The low competitiveness of investment is due to the geographical location, which indicates an earthquake area. Lack of investment support from local governments, especially for licensing services, requires high time and costs-slow development efforts in the economic sector. Furthermore, the direction of economic development is limited to the agricultural and plantation sectors. This research specifically focuses on changes in the economic structure as measured by each economic sector's contribution to employment opportunities in Bengkulu Province from 1983-2017 (35 years), and how is the effect of changes in the economic structure on employment opportunities in Bengkulu Province? 


\section{THEORY}

In the neoclassical economy, the industrial sector wage rate hypothesis limits the function of the marginal productivity of labour (MPL). Whereas in classical economics, the level of wages in the agricultural sector is stated institutionally as living. The interaction of the two sectors base on the surplus of labour generated from the agricultural sector. The existence of change or transition as a characteristic of development is also stated by Zulher C. Ratnasih [1], who defines economic development as a multidimensional process that includes changes in structure, life attitudes, and institutions, apart from increasing economic growth, reducing distribution inequality and poverty eradication. From an employment perspective, Srinivasan [2] argues that development expresses as a transfer of labour from agriculture to industry and services. Transfers that occur and the factors that influence them deeply analyze in various development studies. In the process of structural change in developing countries, Amit Bhaduri in [3] states that the transfer of labour from agriculture to non-agricultural sectors will increase overall labour productivity increase per capita income.

According to [4], changes in economic structure or structural transformation must be able to be expressed by the accumulation of capital, both physical and human, as well as by the transformation of economic structures, both the structure of demand, production, trade, and employment. The transition must be expressed as a level or condition necessary for sustainability and increased income and social welfare [4]. These requirements vary from country to country depending on the social goals and capabilities in production and trade. The processes that form the transition encompass changes in all economic functions, increasing production capacity as measured by the accumulation of capital and skills of the workforce, transformation of resource use, and socio-economic processes.

The rationale for classical theory is that economic development base on a liberal system, in which a passion for maximum benefits spurs economic growth. If profit increases, the saving will increase, and investment will also increase. It will increase the existing capital stock. Production scale increases and increases the demand for labour so that the wage level also increases. When the demand for the number of workers increases, it will increase the supply of labour, which will reduce the level of productivity and profit. Due to the enactment of diminishing returns due to limited amounts of natural resources, such as land area, this process resulted in decreased production, labour demand, and wages. The new strategy must indeed direct efforts to regularly eliminate forms of poverty, the strategy for material or non-material basic needs, to meet the basic needs of the poor.

Hence, it is appropriate if the central core of development targets revolves around poverty eradication, job creation, improving people's welfare, and filling independence in the political fields with economic development. In this process, a fair and equitable distribution of income is realized in various social groups within the groups' scope-developing countries themselves and between countries. By consistently striving for this policy, the target will be achieved nationally so that a developing country is in a stronger position to fight for a new national economic order.

In developing countries where labour is abundant, the technology that saves capital or technology that enlarges the workforce is indispensable. Technology that saves capital in Indonesia is labour-intensive projects (Public Employment Project or Public Service Employment Job). The classification of inventions and innovations such as laboursaving, capital saving, or neutral usually consider using "Isoquant" elementary analysis. Isoquant or the same production field, a focus/place of all combinations/collections, say the pool of capital $(\mathrm{K})$ and the pool of labour (L) produces identical outputs for a given technology.

\section{A. Research Framework}

The effect of changes in the economic structure on employment showed in the following figure:

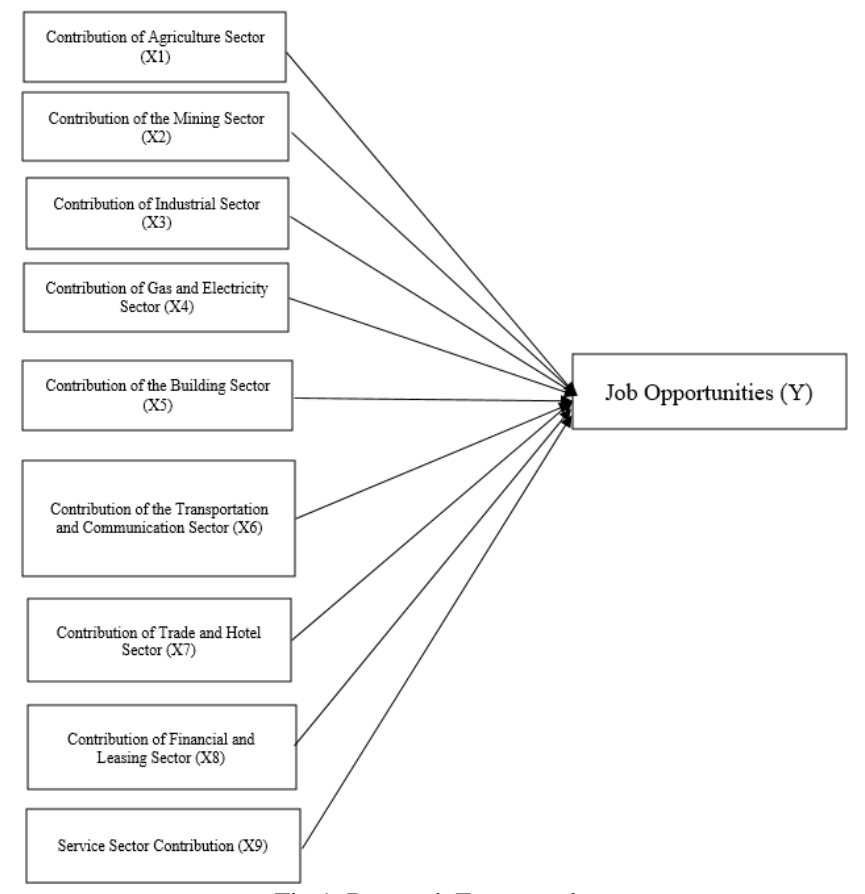

Fig.1. Research Framework.

The model of the effect of changes in the economic structure on employment opportunities above is based on Chenery [4] and developed from Yotopoulos and Nugent's Model of Sectoral Change and Economic Growth [5]. The analytical method used in testing the hypothesis is Regression Analysis. Structural equations were showing a causative relationship.

The hypothesis testing results regarding the effect of Changes in Economic Structure on Job Opportunities showed in the regression equation below.

$$
\begin{gathered}
\operatorname{Ln} \mathrm{Y}=\mathrm{a}+\mathrm{b} 1 \operatorname{Ln} \mathrm{X} 1+\mathrm{b} 2 \operatorname{Ln} \mathrm{X} 2+\mathrm{b} 3 \operatorname{Ln} \mathrm{X} 3+ \\
+\mathrm{b} 4 \operatorname{Ln} \mathrm{X} 4+\mathrm{b} 5 \operatorname{Ln} \mathrm{X} 5+\mathrm{b} 6 \operatorname{Ln} \mathrm{X} 6+\mathrm{b} 7 \operatorname{Ln} \mathrm{X} 7+ \\
+\mathrm{b} 8 \operatorname{Ln} \mathrm{X} 8+\mathrm{b} 9 \operatorname{Ln} \mathrm{X} 9+\mathrm{e} \\
\operatorname{Ln} \mathrm{Y}=-1,812+0,953 \operatorname{Ln} \mathrm{X} 1+0,013 \operatorname{Ln} \mathrm{X} 2- \\
-0,011 \operatorname{Ln} \mathrm{X} 3+0,165 \operatorname{Ln} \mathrm{X} 4+0,168 \operatorname{Ln} \mathrm{X} 5+ \\
+0,667 \operatorname{Ln} \mathrm{X} 6+0,197 \operatorname{Ln} \mathrm{X} 7-0,186 \operatorname{Ln} \mathrm{X} 8+ \\
+0,238 \operatorname{Ln} \mathrm{X} 9+\mathrm{e}
\end{gathered}
$$

where 
$\mathrm{Y}=$ Employment Opportunities;

$\mathrm{X} 1$ = Contribution of the Agricultural Sector;

$\mathrm{X} 2$ = Contribution of the Mining and Excavation Sector;

$\mathrm{X} 3$ = Contribution of the Industrial Sector;

$\mathrm{X} 4$ = Contribution of the Building Sector;

$\mathrm{X} 5$ = Contribution to the Electricity and Drinking Water

Sector;

X6 $=$ Contribution of the Transportation and Communication

Sector;

X7 = Contribution of Trade and Hotel Sector;

$\mathrm{X} 8$ = Financial Sector Contribution and Leases;

X9 = Services Sector Contribution.

Constants: $\mathrm{a}=-1,812$; mathematical price of Job Opportunities if all valuable sector contributions $=0$ (zero). The regression coefficient for agricultural sector contribution: $\mathrm{b} 1=0.953$; if the agricultural sector's contribution increases by 1 unit, under conditions other factors are constant, then job opportunities tend to increase by 0.953 units. The regression coefficient for the mining and quarrying sector's contribution: $b 2=0.013$; If the contribution of the mining and quarrying sector increases by 1 unit, under conditions other factors are constant, then job opportunities tend to increase by 0.013 units. The regression coefficient for industrial sector contribution: $b 3=-0.011$; if the industrial sector's contribution increases by 1 unit, under conditions other factors are constant, then job opportunities tend to decrease by 0.011 units. The regression coefficient for building sector contribution: $\mathrm{b} 4=0.165$; if the building sector's contribution increases by 1 unit, under conditions other factors are constant, then job opportunities tend to increase by 0.165 units. Regression coefficients for the contribution of the electricity and drinking water sector: b5 $=0.168 ;$ if the electricity and drinking water sector's contribution increases by 1 unit, under conditions other factors are constant, then job opportunities tend to increase by 0.168 units. The regression coefficient for the transportation and communication sector's contribution: b6 = 0.667; If the contribution of the transportation and communication sector increases by 1 unit, under conditions other factors are constant, then job opportunities tend to increase by 0.667 units. Regression coefficients for the contribution of the trade and hotel sectors: $b 7=0.197$; if the trade and hotel sectors' contribution increase by 1 unit, under conditions other factors are constant, then job opportunities tend to increase by 0.197 units. Regression coefficients for financial sector contributions and leases: $b 8=-0.186$; If the financial sector's contribution and leases increases by 1 unit, under conditions other factors are constant, then job opportunities tend to decrease by 0.186 units. The regression coefficient for services sector contribution: $b 9=0.238$; if the services sector's contribution increases by 1 unit, under conditions other factors are constant, then job opportunities tend to increase by 0.238 units. It appears that the response to changes in job opportunities due to changes in sector contribution varies according to the type of Sectoral Change and Economic Growth [5].

The research model is structured based on the Cobb Douglas production function [6] used by Yotopoulos and Nugent [5] where the production factors referred to are the contribution or share of each economic sector, as shown below.

$$
\mathrm{Y}=\mathrm{A}_{1} \cdot \mathrm{X}_{1}{ }^{\mathrm{b} 1} \mathrm{X}_{2}{ }^{\mathrm{b} 2} \mathrm{X}_{3}{ }^{\mathrm{b} 3} \mathrm{X}_{4}{ }^{\mathrm{b} 4} \mathrm{X}_{5}{ }^{\mathrm{b} 5} \mathrm{X}_{6}{ }^{\mathrm{b} 6} \mathrm{X}_{7}{ }^{\mathrm{b} 7} \mathrm{X}_{8}{ }^{\mathrm{b} 8} \mathrm{X}_{9}{ }^{\mathrm{b} 9} \mathrm{u}
$$

or in logarithmic form is as follows:

$$
\begin{gathered}
\operatorname{Ln} Y=a+b_{1} \operatorname{Ln} X_{1}+b_{2} \operatorname{Ln} X_{2}+b_{3} \operatorname{Ln} X_{3}+b_{4} \operatorname{Ln} X_{4}+b_{5} \operatorname{Ln} \\
X_{5}+b_{6} \operatorname{Ln} X_{6}+b_{7} \operatorname{Ln} X_{7}+b_{8} \operatorname{Ln} X_{8}+b_{9} \operatorname{Ln} X_{9}+e
\end{gathered}
$$

Note:

$\mathrm{b}_{\mathrm{ij}}>0$ (the contribution of the $\mathrm{i}$-sector in the $\mathrm{j}$-model has a positive effect on $\mathrm{Y}_{\mathrm{j}}$ );

$\mathrm{A}_{\mathrm{j}}=$ Total Multi Sector Productivity;

$\mathrm{a}_{\mathrm{j}}=$ intercept/constant (where $\mathrm{a}_{\mathrm{j}}=\operatorname{Ln~} \mathrm{A}_{\mathrm{j}}$ );

$b_{i j}=$ elasticity of each sector;

$\mathrm{b}_{\mathrm{ij}}=$ the total elasticity of all sectors (the returns to scale);

$\mathrm{Y}_{1}=$ Employment Opportunity;

$\mathrm{X}_{\mathrm{ij}}=$ Contribution from sector $\mathrm{i}$ (sector contribution to job opportunities) in model to-j;

$\mathrm{u}_{\mathrm{j}}, \mathrm{e}_{\mathrm{j}}=$ error/ residue (where $\mathrm{e}_{\mathrm{j}}=\mathrm{Ln} \mathrm{u}_{\mathrm{j}}$ );

$\mathrm{i}=1$ for the Agricultural Sector;

$i=2$ for the Mining and Excavation Sector;

$i=3$ for the Industrial Sector;

$i=4$ for the Building Sector;

$i=5$ for the electricity and drinking water sector;

$i=6$ for the Transportation and Communication Sector;

$i=7$ for the Trade and Hotel Sector;

$i=8$ for the financial sector and leases;

$\mathrm{i}=9$ for the services sector.

The elasticity of each economic sector's contribution (share) to employment opportunities shows a pattern of sectoral changes. In the model above, the economic sector's intensity that supports economic growth is measured by sector intensity. Sector intensity is obtained by calculating the ratio or comparison between a sector's elasticity and other sectors. The total elasticity or the returns to scale measures the magnitude of the change in output if all production factors change in the same proportion. The returns to scale or $\mathrm{v}=1$ indicate constant returns to scale (linear homogeneous) or a constant increase in yield. Returns to scale or $\mathrm{v}<1$ indicate decreasing returns to scale. The returns to scale or v> 1 indicate increasing returns to scale.

When avoiding specification errors, the above models have been subjected to intensive pre-estimation tests, either through theoretical studies of economic structure changes relevant to GRDP growth, per capita income, and employment opportunities and based on in-depth studies of the problem phenomena under study.

\section{METHOD}

In this research, the method used is explanatoryexploratory research. Explanatory because the research aims to explain the relationship (causal or influence) between variables and test the hypothesis. The causal relationship between the variables described is the influence between economic sector changes on employment opportunities.

The subjects in this study were Bengkulu Province, Indonesia. The data used in the measurement of research variables are secondary in time series data in 1983-2017 (35 years). The required data is from the Central Bureau of Statistics (BPS) Bengkulu Province. Indonesia. 
The analytical method used to test the hypothesis regarding changes in the economic sector on employment opportunities is the Multivariate Linear Regression Analysis with the Ordinary Least Square (OLS) technique. The regression analysis technique was chosen with the consideration of the direction of the discussion on the effect test results, the comparison in determining the dominant variable, measuring the size of the variable change response, and the results of the model equation for prediction purposes.

However, the number of data is $n$ where $n>10$ has met the data sufficiency as required. In this study, the amount of data used was $n=35$.

As previously stated, the prerequisites for using OLS in linear regression are classical assumptions regarding the residual or error term (disturbance term) that must meet.

The data processing for all analyzes in this study was conducted using the SPSS (Statistical Product \& Service Solutions) program for Windows Release 22.

\section{RESULT}

The analytical method used in testing the hypothesis is Regression Analysis. Structural equations were showing a causative relationship.

The hypothesis testing results regarding the effect of Changes in Economic Structure on Job Opportunities showed in the regression equation below.

$$
\begin{gathered}
\operatorname{Ln} Y=a+b_{1} \operatorname{Ln} X_{1}+b_{2} \operatorname{Ln} X_{2}+b_{3} \operatorname{Ln} X_{3}+b_{4} \operatorname{Ln} X_{4}+ \\
+b_{5} \operatorname{Ln} X_{5}+b_{6} \operatorname{Ln} X_{6}+b_{7} \operatorname{Ln} X_{7}+b_{8} \operatorname{Ln} X_{8}+b_{9} \operatorname{Ln} X_{9}+e
\end{gathered}
$$$$
\operatorname{Ln} \mathrm{Y}=-1,812+0,953 \operatorname{Ln} \mathrm{X}_{1}+0,013 \operatorname{Ln} \mathrm{X}_{2}-0,011 \operatorname{Ln} \mathrm{X}_{3}+
$$$$
+0,165 \mathrm{Ln} \mathrm{X}_{4}+0,{ }_{168} \operatorname{Ln} \mathrm{X}_{5}+0,667 \mathrm{Ln} \mathrm{X}_{6}+0,197 \mathrm{Ln} \mathrm{X}_{7}-
$$$$
-0,186 \operatorname{Ln} X_{8}+0,238 \operatorname{Ln} X_{9}+e
$$

where

$\mathrm{Y}=$ Employment Opportunities;

$\mathrm{X} 1$ = Contribution of the Agricultural Sector;

$\mathrm{X} 2=$ Contribution of the Mining and Excavation Sector;

$\mathrm{X} 3$ = Contribution of the Industrial Sector;

$\mathrm{X} 4$ = Contribution of the Building SectorX5 = Contribution to the Electricity and Drinking Water Sector;

X6 $=$ Contribution of the Transportation and Communication Sector;

X7 = Contribution of Trade and Hotel Sector;

$\mathrm{X} 8=$ Financial Sector Contribution and Leases;

X9 = Services Sector Contribution.

Constants: $\mathrm{a}=-1,812$; mathematical price of Job Opportunities if all valuable sector contributions $=0$ (zero). The regression coefficient for agricultural sector contribution: $\mathrm{b} 1=0.953$; if the agricultural sector's contribution increases by 1 unit, under conditions other factors are constant, then job opportunities tend to increase by 0.953 units. The regression coefficient for the mining and quarrying sector's contribution: $\mathrm{b} 2=0.013$; If the contribution of the mining and quarrying sector increases by 1 unit, under conditions other factors are constant, then job opportunities tend to increase by 0.013 units. The regression coefficient for industrial sector contribution: $b 3=-0.011$; if the industrial sector's contribution increases by 1 unit, under conditions other factors are constant, then job opportunities tend to decrease by 0.011 units. The regression coefficient for building sector contribution: $\mathrm{b} 4=0.165$; if the building sector's contribution increases by 1 unit, under conditions other factors are constant, then job opportunities tend to increase by 0.165 units. Regression coefficients for the contribution of the electricity and drinking water sector: b5 $=0.168$; if the electricity and drinking water sector's contribution increases by 1 unit, under conditions other factors are constant, then job opportunities tend to increase by 0.168 units. The regression coefficient for the transportation and communication sector's contribution: b6 = 0.667; If the contribution of the transportation and communication sector increases by 1 unit, under conditions other factors are constant, then job opportunities tend to increase by 0.667 units. Regression coefficients for the contribution of the trade and hotel sectors: $\mathrm{b} 7=0.197$; if the trade and hotel sectors' contribution increase by 1 unit, under conditions other factors are constant, then job opportunities tend to increase by 0.197 units. Regression coefficients for financial sector contributions and leases: $b 8=-0.186$; If the financial sector's contribution and leases increases by 1 unit, under conditions other factors are constant, then job opportunities tend to decrease by 0.186 units. The regression coefficient for services sector contribution: $b 9=0.238$; if the services sector's contribution increases by 1 unit, under conditions other factors are constant, then job opportunities tend to increase by 0.238 units. It appears that the response to changes in job opportunities due to changes in sector contribution varies according to the type of sector.

TABLE I: REGRESSION EQUATIONS

\begin{tabular}{|c|c|c|c|c|c|c|}
\hline \multirow{2}{*}{ Model } & & \multicolumn{2}{|c|}{$\begin{array}{c}\text { Unstandardized } \\
\text { Coefficients }\end{array}$} & \multirow{2}{*}{$\begin{array}{c}\begin{array}{c}\text { Standardized } \\
\text { Coefficients }\end{array} \\
\text { Beta }\end{array}$} & \multirow{2}{*}{$\mathrm{t}$} & \multirow{2}{*}{ Sig. } \\
\hline & & B & $\begin{array}{c}\text { Std. } \\
\text { Error }\end{array}$ & & & \\
\hline \multirow{10}{*}{1} & (Constant) & -1.812 & 1.950 & & -0.992 & 0.368 \\
\hline & $\mathrm{X} 1$ & 0.953 & 0.274 & 7.742 & 3.471 & 0.003 \\
\hline & $\mathrm{X} 2$ & 0.013 & 0.012 & 0.453 & 1.032 & 0.319 \\
\hline & X3 & -0.011 & 0.034 & -0.298 & -0.307 & 0.763 \\
\hline & $\mathrm{X} 4$ & 0.165 & 0.052 & 3.365 & 3.195 & 0.006 \\
\hline & $\mathrm{X} 5$ & 0.168 & 0.046 & 4.797 & 3.623 & 0.003 \\
\hline & X6 & 0.667 & 0.211 & 5.892 & 3.159 & 0.006 \\
\hline & $X 7$ & 0.197 & 0.088 & 1.190 & 2.235 & 0.041 \\
\hline & $\mathrm{X} 8$ & -0.186 & 0.065 & -1.901 & -2.844 & 0.012 \\
\hline & $\times 9$ & 0.238 & 0.067 & 3.320 & 3.560 & 0.003 \\
\hline
\end{tabular}
Coefficients $^{\mathrm{a}}$

Dependent Variable: Y.

The magnitude of the effect of changes in the economic structure on job opportunities simultaneously is $66.1 \%$ with a statistical value-F $=3,250$. The multiple correlation coefficient, which is $\mathrm{R}=0.813$, shows that the simultaneous influence of all sector contributions on job opportunities is strong, namely 0.70-0.90 [7].

From the results of the significance test, it found that Fcount is greater than F-table $=2.588(\mathrm{~F}$ table value at $5 \%$ error level and degrees of freedom $\mathrm{db} 1=\mathrm{k}=9, \mathrm{db} 2=\mathrm{nk}-1=$ 15 ), which shows that changes in economic structure have a significant effect simultaneously on opportunities. Work at a $5 \%$ error rate. Thus, $\mathrm{H0}$ is rejected, and the research hypothesis regarding the simultaneous influence of changes in the economic structure on job opportunities is accepted. The magnitude of the influence, in other words, also shows the amount of variation in job opportunities that can be explained by all the causative variables simultaneously, 
namely $\mathrm{R} 2=66.1 \%$. The remainder of the variation, $33.9 \%$ or $1-\mathrm{R} 2$, is explained by other factors not examined.

The partial effect of the agricultural sector's contribution on per capita income is shown by the regression coefficient $\mathrm{b} 1=0.953$ with a statistical value- $\mathrm{t}=3.471$. From the results of the significance test, it found that $\mathrm{t}$ count is greater than $\mathrm{t}$ table $=1.753(\mathrm{t}$ table value at $5 \%$ error level of 1 -sided test type and degrees of freedom nk-1 = 15), which indicates that the contribution of the agricultural sector partially affects job opportunities at the error level 5\%. H0 is rejected, and the research hypothesis regarding the effect of the agricultural sector's partial contribution on job opportunities is accepted. The value of the partial correlation coefficient of $\mid \mathrm{rYX} 1 . \mathrm{Xk}$ $\mid=0.667$ indicates that descriptively the effect of the Partial Contribution of the Agriculture Sector on Job Opportunities is positive and quite strong, 0.40-0.70 [7].

Based on the research results, as a finding, this study shows that the model of the influence of the factors under study on job opportunities has a very high degree of suitability, as reflected in the coefficient of determination. However, in the framework of alternative solutions to increase job opportunities, these modelling results still open up opportunities for further research to develop a model composed of other factors that did not in this research, which theoretically also influence job opportunities.

As a model for a solution to increasing job opportunities, the model test results show that efforts to increase job opportunities to make through efforts to increase the contribution of economic sectors are proven to have a positive direction together. Development policies relevant to increasing employment opportunities are the development of the agricultural sector, the construction sector, the electricity and drinking water sector, the transportation and communication sector, the trade and hotel sector, and the services sector.

\section{DISCUSSION}

The analysis results of the model of the effect of changes in the economic structure on employment growth show mixed results. Changes in the economic structure of the nine economic sectors together or simultaneously affect employment opportunities [8]. The model of the effect of changes in the economic structure on employment opportunities has a determination coefficient of $66.1 \%$. Moreover, the model of the effect of changes in the economic structure on employment growth met the model's expected level of suitability, which is above $50 \%$. For more details, the discussion of the models using the SPSS 22 software is as follows:

The Effect of Economic Structure on Employment Opportunities:

$$
\begin{gathered}
\operatorname{Ln} Y=-1,812+0,953 \operatorname{Ln} X_{1}+0,013 \operatorname{Ln} X_{2}-0,011 \operatorname{Ln} X_{3} \\
(3,471)(1,032)-0,306)+0,165 \operatorname{Ln} X_{4}+0,168 \operatorname{Ln} X_{5}+ \\
+0,667 \operatorname{Ln} X_{6}+0,197(3,195)(3,623)(3,1590(2,235) \\
\operatorname{Ln~} X_{7}-0,186 \operatorname{Ln} X_{8}+0,238 \operatorname{Ln} X_{9}+e \\
(-2,844)(3,560)
\end{gathered}
$$

In this framework, sector-specific developments are analysed in the Employment, with a special focus on labour market trends in the sectors reviewed [9]. In the agricultural sector variable (X1), building sector variable (X4), electricity and drinking water sector variable (X5), transportation and communication sector variable (X6), trade and hotel sector variable (X7), financial sector variable and leases. (X8). Moreover, the services sector variable (X9) proved to affect job opportunities significantly [10]. In this case, it can interpret that if there is an increase in these sectors in units of per cent, it can increase employment opportunities. the growth of the secondary sector and the service sector directly affects the welfare of the community and indirectly affect the welfare of the people through the absorption of labour [11]. In this case, the seven sectors need to get attention from investors because they can reduce unemployment. Meanwhile, the mining and quarrying sector variables (X2) and industrial sector variables (X3) proved insignificant.

In this model, the magnitude of the effect simultaneously is $\mathrm{R} 2=66.1 \%$. The remaining $33.9 \%$ can explain by other factors not examined, such as education, health, environmental, and performance factors.

\section{CONClusion}

1. Changes in Economic Structure have a simultaneous effect on job opportunities. Partially, job opportunities are more positively influenced by the contribution of the agricultural sector (X1), buildings (X4), electricity and drinking water (X5), transportation and communication (X6), trade and hotels (X7), financial and rental sector variables. Rent (X8) and services (X9). The increased contribution from these sectors can increase job opportunities to be higher.

2. In the agricultural sector variable (X1), building sector variable (X4), electricity and drinking water sector variable (X5), transportation and communication sector variable (X6), trade and hotel sector variable (X7), financial and rental sector variable -rent (X8), and services sector variables (X9) proved partially significant effect on job opportunities. to increase the growth of job opportunities to be higher.

3. This model gets a significant influence simultaneously equal to $\mathrm{R} 2=66.1 \%$. The remaining $33.9 \%$ can be explained by other factors that are not examined, such as education factors, health factors, environmental factors, and performance factors.

4. The mining and quarrying sector variable (X2) and the industry sector variable (X3) are proven insignificant.

\section{REFERENCES}

[1] Zulher, C. Ratnasih, "Financial development and poverty reduction in developing countries," Accounting, vol. 7, pp. 667-674, 2021.

[2] Chenery, Hollis and T.N. Srinivasan, Handbook of Development Economics, Handbooks in Economics, vol. 9, Elsevier Science Publishers B.V., Amsterdam, Netherland, 1993.

[3] Ha-Joon Chang (Editor), Rethinking Development Economics. Wimbledon Publishing Company, London, 2003.

[4] Chenery, Hollis, Structural Change and Development Policy, Oxford University Press, 1979.

[5] Yotopoulos and Nugent's Model of Sectoral Change and Economic Growth, pp. 293, 1976. 
[6] A. Koutsoyiannis, Modern Microeconomic, The Macmillan Press. Ltd. London, 1975.

[7] J.P. Guilford, Fundamental Statistic in Psychology and Education. 3rd Ed. New York: McGraw-Hill Book Company, Inc, 1956.

[8] I. Rosyadi, Economic Structure on Gross Regional Domestic Product Growth (Cases in Indonesia), RJOAS, 2019

[9] Robert Stehrer, Terry Ward et al., Sectoral Employment Effects of Economic Downturns, The Vienna Institute for International Economic Studies, 2012.

[10] Miles, David and Andrew Scott, Macroeconomics: Understanding the Wealth of Nations, John Wiley \& Sons, Inc., Chichester, England, 2005.

[11] Nahu Daud, "The Effect of Sector Economic Growth on Performance of Employment and Welfare of People," International Journal of Business and Management, vol. 12, no. 9, ISSN 1833-3850, E-ISSN 1833-8119, Published by Canadian Center of Science and Education, 2017.

[12] O. Ajakaiye, A.T. Jerome, D. Nabena, O.A. Alaba, "Understanding the relationship between growth and employment in Nigeria," WIDWER Working Paper Series 124, World Institute for Development Economic Research (UNU-Widwer), Helsinki, 2016.

[13] BPS Kabupaten Bengkulu Utara, Kabupaten Bengkulu Utara Dalam Angka, Tahun 1983-2017, 2017.

[14] BPS Kabupaten Bengkulu Selatan, Kabupaten Bengkulu Selatan Dalam Angka, Tahun 1983-2017, 2017.

[15] BPS Kota Bengkulu, Kota Bengkulu Dalam Angka, Tahun 1983-20, 2017.

[16] BPS Kabupaten Rejang Lebong, Kabupaten Rejang Lebong Dalam Angka, Tahun 1983-2017, 2017.

[17] Badan Pusat Statistik, Katalog no. 1187, Tahun 2004.

[18] C. Ratnasih, "How financial sector and social overhead capital determine GDP Growth," European Research Studies Journal, vol. $\mathrm{XX}$, issue 3A, pp. 660-672, 2017.

[19] Delong, J. Brad Ford, The Theory of Economic Growth: Macroeconomics, New York: McGraw Hill, 2002.

[20] Gujarati, Damodar, Basic Econometrics, Third Edition, Mc Graw-Hill, New York, 2003.

[21] T. Gylfason, Principles of Economic Growth, Oxford University Press, 1999.

[22] J. Hartwig, "Testing the growth effects of structural change," Structural Change and Economic Dynamics, vol. 23(1), pp. 11-24, 2012.

[23] Hayami, Yujiro, Development Economics: From the Poverty to the Wealth of Nations, Second Edition, Oxford University Press, 2001.

[24] D. Kucera, L. Roncolato, Structure matters: sectoral drivers of growth and the labour productivity-Employment relationship, ILO Research Paper no. 3, December 2012.

[25] J. Kim, dan L. Lau, "The Sources of Economic Growth," Canadian Journal of Economics: Special Issue. Part 2, D. C., The World Bank, 1994.

[26] Kuznets, Simon, Economic Growth and The Contribution of Agriculture, dalam Eicher, C. K. dan Witt, L. W. (ed.), Agriculture in Economic Development, McGraw -Hill, New York, 1964.

[27] Klassen, Purchasing Power Parity: Evidence from a New Test. Center for Economic Research, Tilburg University, Discussion Paper, no. 9909, 1999.

[28] J. Y. Lin, New structural economics: A framework for rethinking development, World Bank Research Observer, vol. 26(2), pp. 193-221, 2011.

[29] Meyer, H. Laurence, Macro Economics: A Model Building Approach. South-Western Publishing Co., Cincinnati, Ohio, USA, 1980.

[30] Pindyck, S. Robert and Rubinfeld, L. Daniel, Econometric Model and Economic Forecast, International Edition, Third Edition, McGrawHill Inc., 1991. 